\title{
Arenimonas donghaensis gen. nov., sp. nov., isolated from seashore sand
}

\author{
Soon-Wo Kwon, ${ }^{1}$ Byung-Yong Kim, ${ }^{1}$ Hang-Yeon Weon, ${ }^{2}$ \\ Youn-Kyung Baek ${ }^{1}$ and Seung-Joo Go ${ }^{1}$
}

Correspondence

Byung-Yong Kim

kimby@rda.go.kr

\begin{abstract}
${ }^{1}$ Korean Agricultural Culture Collection (KACC), Microbial Genetics Division, National Institute of Agricultural Biotechnology, Rural Development Administration (RDA), Suwon 441-707, Republic of Korea

${ }^{2}$ Applied Microbiology Division, National Institute of Agricultural Science and Technology, RDA, Suwon 441-707, Republic of Korea
\end{abstract}

\begin{abstract}
A Gram-negative, aerobic bacterium, designated strain $\mathrm{HO} 3-\mathrm{R} 19^{\top}$, which was isolated from seashore sand in Pohang city, Korea, was characterized on the basis of a polyphasic taxonomic approach. Phylogenetic analyses of $16 \mathrm{~S}$ rRNA gene sequences revealed that strain HO3-R19 ${ }^{\top}$ represents a new lineage within the Gammaproteobacteria; sequence similarities between strain HO3-R $19^{\top}$ and members of other related genera were less than $93.5 \%$. Strain HO3-R19 ${ }^{\top}$ was also distinguished from related genera based on differences in several phenotypic characteristics. Cells were straight or slightly curved rods and formed white colonies on R2A agar. The major isoprenoid quinone was ubiquinone $8(\mathrm{Q}-8)$, and predominant cellular fatty acids were iso- $\mathrm{C}_{16: 0 \text {, }}$, iso- $\mathrm{C}_{15: 0}$ and iso- $\mathrm{C}_{17: 1} \omega 9 \mathrm{c}$. The DNA G $+\mathrm{C}$ content of strain HO3-R19T was $65.0 \mathrm{~mol} \%$. Based on physiological, biochemical and chemotaxonomic traits together with results of comparative $16 \mathrm{~S}$ rRNA sequence analysis, strain $\mathrm{HO} 3-\mathrm{R} 19^{\top}$ is considered to represent a novel species in a new genus, for which the name Arenimonas donghaensis gen. nov., sp. nov. is proposed. The type strain of Arenimonas donghaensis is HO3-R19 ${ }^{\top}\left(=\operatorname{KACC} 11381^{\top}=\mathrm{DSM} 18148^{\top}\right)$.
\end{abstract}

The phylum Proteobacteria represents the largest phylogenetically coherent group of bacteria, comprising over 1300 recognized species (Garrity \& Holt, 2001). During a study of bacterial diversity of oil-contaminated seashore sand by using a culture-dependent approach, a number of bacterial strains were isolated from sand samples. One of these strains, designated HO3-R19 ${ }^{\mathrm{T}}$, forming yellowish-white colonies on R2A agar (Difco) after 3 days cultivation at $28^{\circ} \mathrm{C}$, was isolated from seashore sand in Pohang, Korea. In this study, we report the taxonomic characterization of strain HO3-R19 ${ }^{\mathrm{T}}$, which was considered to represent a member of the class Gammaproteobacteria.

Strain HO3-R $19^{\mathrm{T}}$ was isolated via a dilution plating method onto R2A agar (Difco) after 7 days incubation at $28^{\circ} \mathrm{C}$. The resulting colonies were purified by transferring them onto new plates and subjecting them to an additional incubation for 3 days at $28^{\circ} \mathrm{C}$. Purified colonies were tentatively identified from partial $16 \mathrm{~S}$ rRNA gene sequences.

Colony properties were also observed on R2A medium. Cell morphology was observed via light microscopy (AXIO; Zeiss) and transmission electron microscopy (model 912AB;

The GenBank/EMBL/DDBJ accession number for the 16S rRNA gene sequence of strain $\mathrm{HO}-\mathrm{R} 19^{\top}$ is $\mathrm{DQ} 411038$.
LEO) (Fig. 1). Flagellum type was also determined by transmission electron microscopy. Gram staining of strain HO3-R $19^{\mathrm{T}}$ was determined by using a Gram stain kit (Difco) according to the manufacturer's instructions. Phenotypic tests were performed by using standard procedures (Smibert \& Krieg, 1994). Hydrolysis of carboxymethylcellulose $(0.1 \%$, $\mathrm{w} / \mathrm{v})$, casein $(5.0 \%, \mathrm{w} / \mathrm{v})$, starch $(1.0 \%, \mathrm{w} / \mathrm{v})$, gelatin $(0.4 \%$, $\mathrm{w} / \mathrm{v})$ and tyrosine $(0.5 \%, \mathrm{w} / \mathrm{v})$ was tested as described by Lanyi (1987). Growth at different salinities was tested at 0, 2, $3,5,7$ and $10 \% \mathrm{NaCl}(\mathrm{w} / \mathrm{v})$ on $\mathrm{R} 2 \mathrm{~A}$ broth after cultivation for 7 days. Temperature range for growth was assessed at 4 , $10,15,20,25,30,35,40,45$ and $50^{\circ} \mathrm{C}$ on R2A agar after 15 days incubation. For $\mathrm{pH}$ tests, R2A broth adjusted to initial $\mathrm{pH}$ values of $4,5,6,7,8,9$ and 10 with citrate/ phosphate buffer or Tris/hydrochloride buffer (Breznak \& Costilow, 1994) was used to examine the ability of the strain to grow at different $\mathrm{pH}$ for 15 days. For the nitrate and nitrite reduction tests, the isolate was inoculated into three serum bottles $(25 \mathrm{ml})$ containing $13 \mathrm{ml} \mathrm{R} 2 \mathrm{~A}$ broth, while nitrate and nitrite were added as $\mathrm{KNO}_{3}$ and $\mathrm{NaNO}_{2}$ at concentrations of $10 \mathrm{mM}$. The reduction of nitrate and nitrite was monitored via an ion chromatograph (model IC-320; Dionex) equipped with a conductivity detector and anion exchange column (Metrosep Anion Supp 4; Metrohm).

Enzyme activities, acid production from carbohydrates and assimilation of carbon substrates were determined by using 


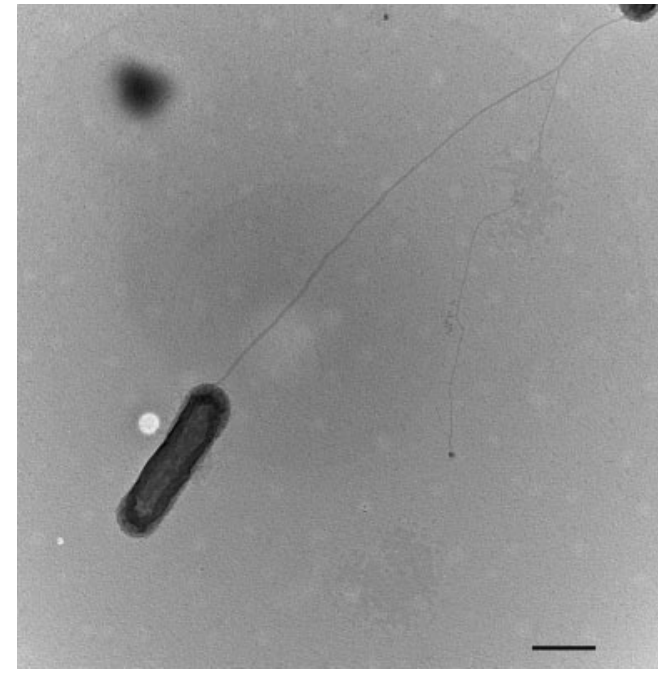

Fig. 1. Transmission electron micrograph of a cell of strain HO3-R19 ${ }^{\top}$. Bar, $500 \mathrm{~nm}$.

API 20NE and API ZYM test strips (bioMérieux) according to the manufacturer's instructions. API 20NE strips were read visually after 24 and $48 \mathrm{~h}$ incubation at $28^{\circ} \mathrm{C}$. For strain characterization, only values taken after $48 \mathrm{~h}$ were taken into account. API ZYM strips were read after $5 \mathrm{~h}$ incubation. Anaerobic growth was observed after incubation in an anaerobic chamber for 15 days at $28^{\circ} \mathrm{C}$ on R2A agar. Strain HO3-R19 ${ }^{\mathrm{T}}$ was tested for its susceptibility to nine antimicrobial compounds by using the method described by Alves et al. (2003). The isolate was incubated on R2A plates with discs (bioMérieux) containing ampicillin $(10 \mu \mathrm{g})$, erythromycin $(30 \mu \mathrm{g})$, fusidic acid $(10 \mu \mathrm{g})$, gentamicin $(10 \mu \mathrm{g})$, kanamycin $(30 \mu \mathrm{g})$, lincomycin $(15 \mu \mathrm{g})$, neomycin $(30 \mu \mathrm{g})$, penicillin $\mathrm{G}(10 \mathrm{IU})$ or streptomycin $(10 \mu \mathrm{g})$.

The following chemotaxonomic characteristics were analysed: isoprenoid quinone (as described by Groth et al., 1996), fatty acids (according to the standard protocol of the
MIDI/Hewlett Packard Microbial Identification System; Sasser, 1990) and G + C content of the DNA (Mesbah et al., 1989).

The 16S rRNA gene sequence of strain HO3-R19 ${ }^{\mathrm{T}}$ was analysed as described by Kwon et al. (2003). Phylogenetic analysis was performed by using the program MEGA, version 3.1 (Kumar et al., 2004), after multiple alignment of the data by using CLUSTAL W (Thompson et al., 1994). Distances were obtained by using options according to the Kimura twoparameter model (Kimura, 1980) and clustering was performed by using the neighbour-joining (Saitou \& Nei, 1987) and maximum-parsimony (Fitch, 1971) methods. Bootstrap values from 1000 replications were used to obtain the confidence level of the branches (Felsenstein, 1985).

Comparative analysis of the 16S rRNA gene sequence with those of the type species of related genera indicated that strain HO3-R19 $9^{\mathrm{T}}$ was a member of the family Xanthomonadaceae and had a unique taxonomic position within the class Gammaproteobacteria. The tree constructed based on the neighbour-joining method indicated that strain HO3 $-\mathrm{R} 19^{\mathrm{T}}$ formed a phyletic line that was distinct from those occupied by the type species of the closely related genera Pseudoxanthomonas, Thermomonas, Silanimonas, Lysobacter, Luteimonas, Stenotrophomonas, Xylella and Xanthomonas (Fig. 2). The topology of the phylogenetic tree based on the maximum-parsimony algorithm was similar to that of the tree constructed by using neighbourjoining analysis (data not shown). According to a BLAST search within the NCBI database, strain HO3-R $19^{\mathrm{T}}$ showed highest 16S rRNA gene sequence similarity to Pseudoxanthomonas suwonensis $4 \mathrm{M}^{\mathrm{T}}(93.5 \%)$. Strain HO3-R $19^{\mathrm{T}}$ was also closely related to Pseudoxanthomonas broegbernensis DSM $12573^{\mathrm{T}}$ and Silanimonas lenta $25-4^{\mathrm{T}}$, but with only 93.0 and $92.6 \%$ 16S rRNA gene sequence similarity, respectively.

Cells of strain HO3-R19 ${ }^{\mathrm{T}}$ were aerobic, Gram-negative, motile, straight or slightly curved rods, $0.4-0.6 \mu \mathrm{m}$ in width and $1.3-3.0 \mu \mathrm{m}$ in length. One polar flagellum was observed

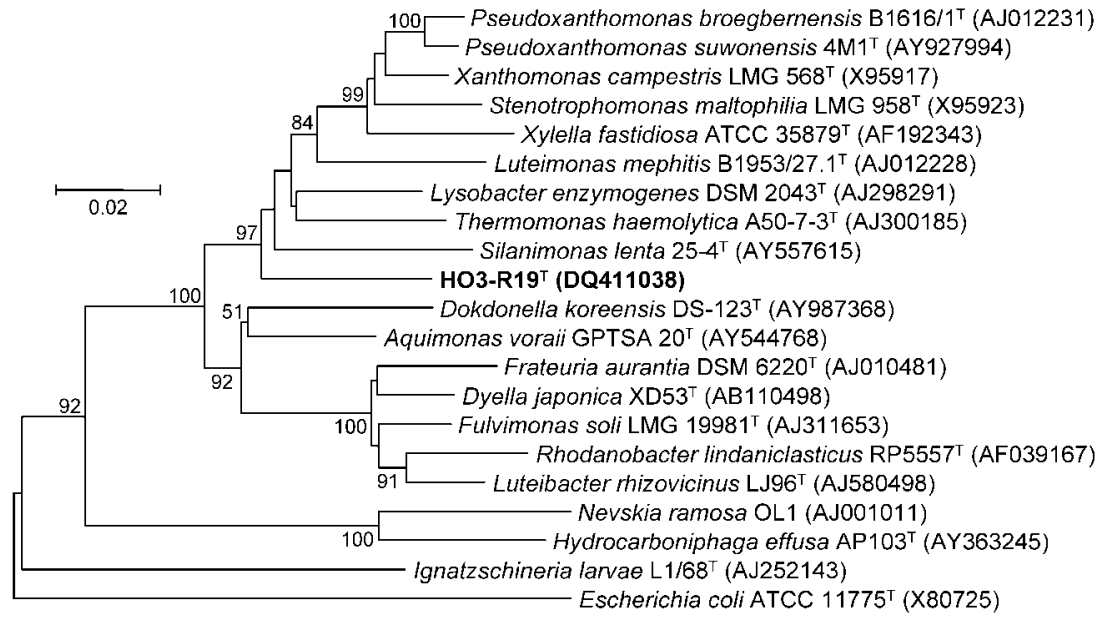

Fig. 2. Phylogenetic relationships between strain $\mathrm{HO}-\mathrm{R} 19^{\top}$ and related taxa on the basis of $16 \mathrm{~S}$ rRNA gene sequences. The phylogenetic tree was constructed by using the neighbour-joining method (Saitou \& Nei, 1987), and the 16S rRNA gene sequence of Escherichia coli ATCC $11775^{\top}$ was used as the outgroup. Numbers at nodes indicate levels of bootstrap support (\%) based on a neighbour-joining analysis of 1000 resampled datasets; values $<50 \%$ are not indicated. Bar, 0.02 nucleotide substitutions per site. 
under transmission electron microscopy, as with cells of other closely related taxa except Lysobacter enzymogenes. Colonies on R2A agar after 3 days incubation at $28^{\circ} \mathrm{C}$ were yellowish white. Strain $\mathrm{HO} 3-\mathrm{R} 19^{\mathrm{T}}$ was positive for oxidase and catalase activities. It did not grow anaerobically. Strain $\mathrm{HO} 3-\mathrm{R} 19^{\mathrm{T}}$ grew in the temperature range $4-37^{\circ} \mathrm{C}$, with an optimum at $28^{\circ} \mathrm{C}$, contrasting markedly with Thermomonas haemolytica, Stenotrophomonas maltophilia and Silanimonas lenta. The $\mathrm{pH}$ for growth was in the range 7.0-9.0 with an optimum at $\mathrm{pH}$ 8.0. The strain also hydrolysed tyrosine, gelatin, DNA and casein. It tolerated up to $3 \% \mathrm{NaCl}(\mathrm{w} / \mathrm{v})$. Strain $\mathrm{HO} 3-\mathrm{R} 19^{\mathrm{T}}$ was sensitive to erythromycin, fusidic acid, gentamicin, kanamycin, neomycin and streptomycin, and resistant to ampicillin, lincomycin and penicillin G.

The major respiratory lipoquinone of strain $\mathrm{HO} 3-\mathrm{R} 19^{\mathrm{T}}$ was ubiquinone $8(\mathrm{Q}-8)$, as with closely related taxa. After incubation for 3 days at $28^{\circ} \mathrm{C}$ on R2A, the cellular fatty acids of strain $\mathrm{HO} 3-\mathrm{R}_{1} 9^{\mathrm{T}}$ included iso- $\mathrm{C}_{16: 0}(31.0 \%)$, iso- $\mathrm{C}_{15: 0}$ $(26.9 \%)$, iso- $\mathrm{C}_{17: 1} \omega 9 c(14.7 \%)$, iso- $\mathrm{C}_{14: 0}(6.4 \%)$, iso$\mathrm{C}_{11: 0} 3-\mathrm{OH}(5.5 \%)$, iso- $\mathrm{C}_{15: 1} \mathrm{~F}(2.9 \%)$, summed feature 3 (iso- $\mathrm{C}_{15: 0} 2-\mathrm{OH}$ and/or $\left.\mathrm{C}_{16: 1} \omega 9 c ; 2.7 \%\right)$, iso- $\mathrm{C}_{11: 0}(2.2 \%)$, summed feature $1\left(\mathrm{C}_{13: 0} 3-\mathrm{OH}\right.$ and/or iso- $\left.\mathrm{C}_{15: 1} \mathrm{H} ; 1.8 \%\right)$, iso- $\mathrm{C}_{16: 1} \mathrm{H}(1.2 \%)$ and iso- $\mathrm{C}_{17: 0}(1.1 \%)$. The iso-branched fatty acids iso- $\mathrm{C}_{16: 0}$, iso- $\mathrm{C}_{15: 0}$ and iso- $\mathrm{C}_{17: 1} \omega 9 \mathrm{c}$ as major components are also characteristic of $T$. haemolytica, Silanimonas lenta and Aquimonas voraii but not of some other related genera. The predominant hydroxy fatty acid of strain $\mathrm{HO} 3-\mathrm{R}_{1} 9^{\mathrm{T}}$ was iso- $\mathrm{C}_{11: 0} 3-\mathrm{OH}$, as is also the case for Silanimonas lenta, T. haemolytica, Luteimonas mephitis, Lysobacter enzymogenes and A. voraii. By contrast, some related taxa ( $P$. broegbernensis, Stenotrophomonas maltophilia, Xylella fastidiosa and Xanthomonas campestris) contained hydroxy fatty acids that were not detected in strain HO3-R19 ${ }^{\mathrm{T}}$ (Table 1).

Strain HO3-R19 $9^{\mathrm{T}}$ contained diphosphatidylglycerol, phosphatidylglycerol and phosphatidylethanolamine as major polar lipids in addition to small amounts of an unknown phospholipid and two unidentified spots inferring the presence of two aminophospholipids. The presence of these unidentified polar lipids could also be used to distinguish strain $\mathrm{HO} 3-\mathrm{R} 19^{\mathrm{T}}$ from related genera. The $\mathrm{G}+\mathrm{C}$ content of the genomic DNA was $65.0 \mathrm{~mol} \%$, a value much higher than for Silanimonas lenta $(50.7 \mathrm{~mol} \%)$ and Xylella fastidiosa (about $51-53 \mathrm{~mol} \%$ ) but lower than for $A$. voraii (75 mol\%), P. broegbernensis (70.1 mol\%), L. enzymogenes (69-70 $\mathrm{mol} \%)$ and T. haemolytica $(68.5 \mathrm{~mol} \%)$. Characteristics that differentiate strain $\mathrm{HO} 3-\mathrm{R} 19^{\mathrm{T}}$ from phylogenetically related species are given in Table 1; other detailed characteristics determined are given in the species description below.

In conclusion, the $16 \mathrm{~S}$ rRNA gene sequence, physiological characteristics, fatty acid profile and DNA G + C content of strain $\mathrm{HO} 3-\mathrm{R} 19^{\mathrm{T}}$ were quite different from those of its phylogenetic neighbours. In addition, the closest similarity $(93.5 \%)$ of the $16 \mathrm{~S}$ rRNA gene sequence of strain HO3-R $19^{\mathrm{T}}$ with a recognized bacterium (the type strain of $P$. suwonensis) was much lower than the threshold level that is generally used to define a new genus (Ludwig et al., 1998). Therefore, we propose that isolate HO3-R $19^{\mathrm{T}}$ should be classified as representing a novel species in a new genus, Arenimonas donghaensis gen. nov., sp. nov., within the family Xanthomonadaceae, class Gammaproteobacteria.

\section{Description of Arenimonas gen. nov.}

Arenimonas (A.re' ni.mo.nas. L. fem. n. arena sand; L. fem. n. monas a unit, monad; N.L. fem. n. Arenimonas a sand monad, referring to a bacterium isolated from sand).

Cells are aerobic, Gram-negative, non-spore-forming rods. Oxidase- and catalase-positive. Nitrate and nitrite are not reduced. Major isoprenoid quinone is Q-8. Predominant cellular fatty acids are iso-branched, such as iso- $\mathrm{C}_{16: 0 \text {, iso- }}$ $\mathrm{C}_{15: 0}$ and iso- $\mathrm{C}_{17: 1} \omega 9 \mathrm{c}$. Phylogenetically, the genus belongs to the family Xanthomonadaceae within the class Gammaproteobacteria. The type species is Arenimonas donghaensis.

\section{Description of Arenimonas donghaensis sp. nov.}

Arenimonas donghaensis (dong.ha.en'sis. N.L. fem. adj. donghaensis pertaining to Donghae, the Korean name of the East Sea of Korea, where the type strain was isolated).

Cells are straight or slightly curved rods that are $0.4-0.6 \mu \mathrm{m}$ wide and 1.3-3.0 $\mu \mathrm{m}$ long. Colonies are yellowish white, translucent and convex on R2A agar after 3 days cultivation. Motile by means of a single polar flagellum. The $\mathrm{pH}$ range for growth is 7.0-9.0, with an optimum at $\mathrm{pH}$ 8.0. The temperature range for growth is $4-37^{\circ} \mathrm{C}$, with an optimum at $28{ }^{\circ} \mathrm{C}$. Growth occurs at $\mathrm{NaCl}$ concentrations of $0-3 \%$ $(\mathrm{w} / \mathrm{v})$ (optimum of 1-2\%). Does not grow under anaerobic conditions. Positive for hydrolysis of casein, tyrosine, DNA and gelatin. Negative for indole production, VogesProskauer test, phenylalanine deamination and hydrolysis of starch, urea and cellulose. In API 20NE tests, cells are positive only for hydrolysis of gelatin, and negative for nitrate reduction, indole production, glucose fermentation, arginine dihydrolase, urease, aesculin hydrolysis, $\beta$-galactosidase and assimilation of D-glucose, L-arabinose, D-mannose, D-mannitol, $\mathrm{N}$-acetylglucosamine, D-maltose, potassium gluconate, capric acid, adipic acid, malic acid, trisodium citrate and phenylacetic acid. In API ZYM tests, cells are positive for alkaline phosphatase, esterase (C4), esterase lipase (C8), trypsin, $\alpha$-chymotrypsin, acid phosphatase and naphthol-AS-BI-phosphohydrolase, but negative for lipase (C14), leucine arylamidase, valine arylamidase, cystine arylamidase, $\alpha$-galactosidase, $\beta$-galactosidase, $\beta$-glucuronidase, $\alpha$-glucosidase, $\beta$-glucosidase, $N$-acetylglucosaminidase, $\alpha$-mannosidase and $\alpha$-fucosidase. Predominant polar lipids are diphosphatidylglycerol, phosphatidylglycerol, phosphatidylethanolamine, a small amount of an unknown phospholipid and two unknown aminophospholipids. Major fatty acids are iso- $\mathrm{C}_{16: 0}$, 
Table 1. Characteristics used to distinguish between strain $\mathrm{HO}-\mathrm{R} 19^{\top}$ and other closely related bacteria

Taxa: 1, strain HO3-R19 ${ }^{\mathrm{T}}$; 2, Thermomonas haemolytica; 3, Luteimonas mephitis; 4, Pseudoxanthomonas broegbernensis; 5, Stenotrophomonas maltophilia; 6, Xylella fastidiosa; 7, Xanthomonas campestris; 8, Lysobacter enzymogenes; 9, Silanimonas lenta; 10, Aquimonas voraii. Data for reference taxa were taken from Busse et al. (2002), Chen et al. (2002), Tóth et al. (2001), Finkmann et al. (2000), Vauterin et al. (1995, 1996), Palleroni \& Bradbury (1993), Wells et al. (1987), Palleroni (1984), Christensen \& Cook (1978), Sullivan et al. (2003), Lee et al. (2005) and Saha et al. (2005). NA, No data available.

\begin{tabular}{|c|c|c|c|c|c|c|c|c|c|c|}
\hline Characteristic & 1 & 2 & 3 & 4 & 5 & 6 & 7 & 8 & 9 & 10 \\
\hline Motility & + & + & NA & + & + & + & + & - & + & + \\
\hline Temperature optimum $\left({ }^{\circ} \mathrm{C}\right)$ & 28 & $37-50$ & 28 & 28 & 35 & $26-28$ & 28 & $25-35$ & 47 & 30 \\
\hline Catalase & + & + & NA & + & + & + & + & + & + & + \\
\hline Oxidase & + & + & NA & + & + & - & - & + & + & + \\
\hline Nitrate reduction & - & - & - & - & + & - & - & - & - & - \\
\hline Aesculin hydrolysis & - & - & - & - & + & - & + & + & - & - \\
\hline \multicolumn{11}{|l|}{ Susceptibility ${ }^{*}$ to: } \\
\hline Ampicillin $(10 \mu \mathrm{g})$ & - & + & - & - & - & + & - & NA & + & NA \\
\hline Penicillin G (10 IU) & - & + & - & - & - & - & - & - & + & $\mathrm{NA}$ \\
\hline Erythromycin $(30 \mu \mathrm{g})$ & + & + & - & - & - & NA & - & NA & + & NA \\
\hline Kanamycin $(30 \mu \mathrm{g})$ & + & + & $\mathrm{v}+$ & - & + & + & + & NA & + & NA \\
\hline Neomycin $(30 \mu \mathrm{g})$ & + & + & $\mathrm{v}-$ & + & - & NA & - & NA & + & NA \\
\hline Streptomycin $(10 \mu \mathrm{g})$ & + & + & - & - & - & - & + & - & + & NA \\
\hline Major fatty acids & $\begin{array}{l}\text { iso- } \mathrm{C}_{16: 0} \\
\text { iso- } \mathrm{C}_{15: 0} \\
\text { iso- } \mathrm{C}_{17: 1} \omega 9 c\end{array}$ & $\begin{array}{l}\text { iso- } C_{15: 0} \\
\text { iso- }-C_{16: 0}\end{array}$ & $\begin{array}{l}\text { iso- } \mathrm{C}_{15: 0}, \\
\text { iso- } \mathrm{C}_{17: 1} \text {, } \\
\text { iso- } \mathrm{C}_{17: 0}\end{array}$ & $\begin{array}{c}\text { iso- } \mathrm{C}_{15: 0} \\
\text { anteiso- } \mathrm{C}_{15: 0} \\
\mathrm{C}_{16: 0}\end{array}$ & $\begin{array}{l}\text { iso- } \mathrm{C}_{15: 0} \\
\text { anteiso- } \mathrm{C}_{15: 0}\end{array}$ & $\begin{array}{c}\mathrm{C}_{16: 0}, \mathrm{C}_{16: 1} \\
\mathrm{C}_{17: 0}\end{array}$ & $\begin{array}{l}\text { iso- } \mathrm{C}_{15: 0} \\
\mathrm{C}_{16: 1}, \\
\text { iso- } \mathrm{C}_{17: 1}\end{array}$ & $\begin{array}{l}\text { iso- } C_{15: 0} \\
\text { iso- } C_{17: 1} \omega 9 c\end{array}$ & $\begin{array}{l}\text { iso- } C_{15: 0} \\
\text { iso- } C_{16: 0}\end{array}$ & 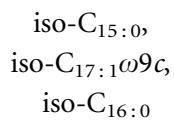 \\
\hline Major hydroxy fatty acids & $\begin{array}{c}\text { iso- } \mathrm{C}_{11: 0} \\
3-\mathrm{OH}\end{array}$ & $\begin{array}{c}\text { iso- } \mathrm{C}_{11: 0} \\
3-\mathrm{OH}\end{array}$ & $\begin{array}{c}\text { iso- } \mathrm{C}_{11: 0} \\
3-\mathrm{OH}\end{array}$ & $\mathrm{C}_{16: 0} 2-\mathrm{OH}$ & $\begin{array}{c}\mathrm{C}_{13: 0} \text { iso } \\
3-\mathrm{OH}\end{array}$ & $\mathrm{C}_{10: 0} 2-\mathrm{OH}$ & $\begin{array}{c}\text { iso- } \mathrm{C}_{13: 0} \\
3-\mathrm{OH}\end{array}$ & $\begin{array}{c}\text { iso- } \mathrm{C}_{11: 0} \\
3-\mathrm{OH}\end{array}$ & $\begin{array}{c}\text { iso- } \mathrm{C}_{11: 0} \\
3-\mathrm{OH}\end{array}$ & $\begin{array}{c}\text { iso- } \mathrm{C}_{11: 0} \\
3-\mathrm{OH}\end{array}$ \\
\hline Major polar lipids $\dagger$ & $\begin{array}{c}\text { DPG, PE, PG, } \\
\text { PL, APL }\end{array}$ & $\begin{array}{c}\text { DPG, PE, } \\
\text { PG }\end{array}$ & NA & NA & DPG, PE, PG & NA & $\begin{array}{c}\text { DPG, PE, PG, } \\
\text { PME, PL }\end{array}$ & NA & $\begin{array}{l}\text { DPG, PE, } \\
\text { PG, PL }\end{array}$ & NA \\
\hline DNA G $+\mathrm{C}$ content $(\mathrm{mol} \%)$ & 65.0 & 68.5 & NA & 70.1 & $62-66$ & $51-53$ & $65-66$ & $69-70$ & 50.7 & 75 \\
\hline
\end{tabular}

${ }^{\star} \mathrm{V}+$, Most strains not susceptible; $\mathrm{V}-$, most strains susceptible.

†APL, Unknown aminophospholipid; DPG, diphosphatidylglycerol; PE, phosphatidylethanolamine; PG, phosphatidylglycerol; PL, unknown phospholipid; PME, phosphatidylmethylethanolamine. 
iso- $\mathrm{C}_{15: 0}$ and iso- $\mathrm{C}_{17: 1} \omega 9 c$ when grown on $\mathrm{R} 2 \mathrm{~A}$ for 3 days. The DNA G + C content is $65.0 \mathrm{~mol} \%$ (HPLC).

The type strain, HO3-R19 ${ }^{\mathrm{T}}\left(=\mathrm{KACC} 11381^{\mathrm{T}}=\mathrm{DSM}\right.$ $\left.18148^{\mathrm{T}}\right)$, was isolated from seashore sand in Pohang, Korea.

\section{Acknowledgements}

We are grateful to Dr J. P. Euzéby for help with nomenclature and two anonymous reviewers for meticulous reading of earlier versions of the manuscript. This study was supported by the Agricultural Research \& Promotion Center, Republic of Korea.

\section{References}

Alves, M. P., Rainey, F. A., Nobre, M. F. \& da Costa, M. S. (2003). Thermomonas hydrothermalis sp. nov., a new slightly thermophilic $\gamma$ proteobacterium isolated from a hot spring in central Portugal. Syst Appl Microbiol 26, 70-75.

Breznak, J. A. \& Costilow, R. N. (1994). Physicochemical factors in growth. In Methods for General and Molecular Bacteriology, pp. 137-154. Edited by P. Gerhardt, R. G. E. Murray, W. A. Wood \& N. R. Krieg. Washington, DC: American Society for Microbiology.

Busse, H.-J., Kämpfer, P., Moore, E. R. B., Nuutinen, J., Tsitko, I. V., Denner, E. B. M., Vauterin, L., Valens, M., Rosselló-Mora, R. \& Salkinoja-Salonen, M. S. (2002). Thermomonas haemolytica gen. nov., sp. nov., a $\gamma$-proteobacterium from kaolin slurry. Int J Syst Evol Microbiol 52, 473-483.

Chen, M. Y., Tsay, S. S., Chen, K. Y., Shi, Y. C., Lin, Y. T. \& Lin, G. H. (2002). Pseudoxanthomonas taiwanensis sp. nov., a novel thermophilic, $\mathrm{N}_{2} \mathrm{O}$-producing species isolated from hot springs. Int J Syst Evol Microbiol 52, 2155-2161.

Christensen, P. \& Cook, F. D. (1978). Lysobacter, a new genus of nonfruiting, gliding bacteria with a high base ratio. Int $J$ Syst Bacteriol 28, 367-393.

Felsenstein, J. (1985). Confidence limits on phylogenies: an approach using the bootstrap. Evolution 39, 783-791.

Finkmann, W., Altendorf, K., Stackebrandt, E. \& Lipski, A. (2000). Characterization of $\mathrm{N}_{2} \mathrm{O}$-producing Xanthomonas-like isolates from biofilters as Stenotrophomonas nitritireducens sp. nov., Luteimonas mephitis gen. nov., sp. nov. and Pseudoxanthomonas broegbernensis gen. nov., sp. nov. Int J Syst Evol Microbiol 50, 273-282.

Fitch, W. M. (1971). Toward defining the course of evolution: minimum change for a specific tree topology. Syst Zool 20, 406-416.

Garrity, G. M. \& Holt, J. G. (2001). The road map to the Manual. In Bergey's Manual of Systematic Bacteriology, 2nd edn, vol. 1, pp. 119-166. Edited by D. R. Boone, R. W. Castenholz \& G. M. Garrity. New York: Springer.

Groth, I., Schumann, P., Weiss, N., Martin, K. \& Rainey, F. A. (1996). Agrococcus jenensis gen. nov., sp. nov., a new genus of actinomycetes with diaminobutyric acid in the cell wall. Int J Syst Bacteriol 46, 234-239.

Kimura, M. (1980). A simple method for estimating evolutionary rates of base substitutions through comparative studies of nucleotide sequences. J Mol Evol 16, 111-120.

Kumar, S., Tamura, K. \& Nei, M. (2004). MEGA3: integrated software for molecular evolutionary genetics analysis and sequence alignment. Brief Bioinform 5, 150-163.
Kwon, S. W., Kim, J. S., Park, I. C., Yoon, S. H., Park, D. H., Lim, C. K. \& Go, S. J. (2003). Pseudomonas koreensis sp. nov., Pseudomonas umsongensis sp. nov. and Pseudomonas jinjuensis sp. nov., novel species from farm soils in Korea. Int J Syst Evol Microbiol 53, 21-27.

Lanyi, B. (1987). Classical and rapid identification methods for medically important bacteria. Methods Microbiol 19, 1-67.

Lee, E. M., Jeon, C. O., Choi, I., Chang, K.-S. \& Kim, C.-J. (2005). Silanimonas lenta gen. nov., sp. nov., a slightly thermophilic and alkaliphilic gammaproteobacterium isolated from a hot spring. Int J Syst Evol Microbiol 55, 385-389.

Ludwig, W., Strunk, O., Klugbauer, S., Klugbauer, N., Weizenegger, M., Neumaier, J., Bachleitner, M. \& Schleifer, K. H. (1998). Bacterial phylogeny based on comparative sequence analysis. Electrophoresis 19, 554-568.

Mesbah, M., Premachandran, U. \& Whitman, W. B. (1989). Precise measurement of the $\mathrm{G}+\mathrm{C}$ content of deoxyribonucleic acid by highperformance liquid chromatography. Int J Syst Bacteriol 39, 159-167. Palleroni, N. J. (1984). Genus I. Pseudomonas Migula 1894, 237 ${ }^{\mathrm{AL}}$. In Bergey's Manual of Systematic Bacteriology, vol. 1, pp. 141-199. Edited by N. R. Krieg \& J. G. Holt. Baltimore: Williams \& Wilkins.

Palleroni, N. J. \& Bradbury, J. F. (1993). Stenotrophomonas, a new bacterial genus for Xanthomonas maltophilia (Hugh 1980) Swings et al. 1983. Int J Syst Bacteriol 43, 606-609.

Saha, P., Krishnamurthi, S., Mayilraj, S., Prasad, G. S., Bora, T. C. \& Chakrabarti, T. (2005). Aquimonas voraii gen. nov., sp. nov., a novel gammaproteobacterium isolated from a warm spring of Assam, India. Int J Syst Evol Microbiol 55, 1491-1495.

Saitou, N. \& Nei, M. (1987). The neighbor-joining method: a new method for reconstructing phylogenetic trees. Mol Biol Evol 4, 406-425.

Sasser, M. (1990). Identification of bacteria by gas chromatography of cellular fatty acids, MIDI Technical Note 101. Newark, DE: MIDI Inc.

Smibert, R. M. \& Krieg, N. R. (1994). Phenotypic characterization. In Methods for General and Molecular Bacteriology, pp. 607-654. Edited by P. Gerhardt, R. G. E. Murray, W. A. Wood \& N. R. Krieg. Washington, DC: American Society for Microbiology.

Sullivan, R. F., Holtman, M. A., Zylstra, G. J., White, J. F., Jr \& Kobayashi, D. Y. (2003). Taxonomic positioning of two biological control agents for plant diseases as Lysobacter enzymogenes based on phylogenetic analysis of $16 \mathrm{~S}$ rDNA, fatty acid composition and phenotypic characteristics. J Appl Microbiol 94, 1079-1086.

Thompson, J. D., Higgins, D. G. \& Gibson, T. J. (1994). CLUSTAL W: improving the sensitivity of progressive multiple sequence alignment through sequence weighting, position-specific gap penalties and weight matrix choice. Nucleic Acids Res 22, 4673-4680.

Tóth, E., Kovács, G., Schumann, P., Kovács, A. L., Steiner, U., Halbritter, A. \& Márialigeti, K. (2001). Schineria larvae gen. nov., sp. nov., isolated from the 1st and 2nd larval stages of Wohlfahrtia magnifica (Diptera: Sarcophagidae). Int J Syst Evol Microbiol 51, 401-407.

Vauterin, L., Hoste, B., Kersters, K. \& Swings, J. (1995). Reclassification of Xanthomonas. Int J Syst Bacteriol 45, 472-489.

Vauterin, L., Yang, P. \& Swings, J. (1996). Utilization of fatty acid methyl esters for the differentiation of new Xanthomonas species. Int J Syst Bacteriol 46, 298-304.

Wells, J. M., Raju, B. C., Hung, H.-Y., Weisburg, W. G., MandelcoPaul, L. \& Brenner, J. (1987). Xylella fastidiosa gen. nov., sp. nov.: gram-negative, xylem-limited, fastidious plant bacteria related to Xanthomonas spp. Int J Syst Bacteriol 37, 136-143. 